\title{
PENGARUH WAKTU ULTRASONIKASI TERHADAP KARAKTERISTIK FISIKA NANOPARTIKEL KITOSAN EKSTRAK ETANOL DAUN SUJI (Pleomele angustifolia) DAN UJI STABILITAS FISIKA MENGGUNAKAN METODE CYCLING TEST
}

\author{
Malinda Prihantini", Elya Zulfa, Listyana Dewi Prastiwi, Ikha Dyah Yulianti \\ Bidang Farmasetika dan Teknologi Farmasi, Fakultas Farmasi, Universitas Wahid Hasyim \\ Jl. Menoreh Tengah X/22 Semarang 50236 Sampangan Semarang \\ E-mail: malindap@unwahas.ac.id
}

\begin{abstract}
INTISARI
Sistem nanopartikel mengenkapsulasi dan melindungi flavonoid pada daun suji dari ketidakstabilan fotolisis dan oksidasi. Kitosan merupakan polimer pembentuk nanopartikel yang bersifat biokompatibel, biodegradabel dan tidak toksik. Ultrasonikasi merupakan teknik pencampuran dengan energi getaran tinggi. Waktu ultrasonikasi mempengaruhi ukuran partikel. Tujuan penelitian ini untuk mengetahui pengaruh waktu utrasonikasi terhadap karakteristik fisika nanopartikel kitosan ekstrak etanol daun suji (Pleomele angustifolia) dan mengetahui stabilitas fisikanya setelah cycling test. Ekstrak etanol daun suji (EEDS) diperoleh dengan maserasi menggunakan etanol 70\%. Nanopartikel kitosan EEDS dibuat menggunakan metode gelasi ionik dengan waktu ultrasonikasi 3 menit (FI), 6 menit (FII), dan 9 menit (FIII). Karakterisasi fisika nanopartikel meliputi ukuran partikel, indeks polidispersitas, dan potensial zeta. Nanopartikel kitosan EEDS dengan karakteristik fisika terbaik (FIII) diuji stabilitasnya menggunakan metode cycling test. Data yang diperoleh dianalisis menggunakan metode statistika Anova dengan taraf kepercayaan 95\%. Ukuran nanopartikel kitosan EEDS (nm) berbeda bermakna pada semua formula, FI $(374,47)$, FII $(288,43)$, dan FIII $(233,37)$. Indeks polidispersitas FI $(0,38)$ dan FIII $(0,65)$ berbeda bermakna, FII $(0,41)$ berbeda tidak bermakna. Potensial zeta $(\mathrm{mV})$ FI $(51,70)$, FII $(46,10)$, dan FIII $(48,60)$ berbeda tidak bermakna pada semua formula. Karakteristik fisika FIII setelah cycling test menunjukkan ukuran partikel $455,0 \mathrm{~nm}$, indeks polidispersitas 0,174 , dan potensial zeta $20,1 \mathrm{mV}$.
\end{abstract}

Kata kunci: ultrasonikasi, nanopartikel, kitosan, cycling test, daun suji (Pleomele angustifolia)

\begin{abstract}
The nanoparticle system encapsulates and protects flavonoids of suji leaves from photolysis and oxidation instability. Chitosan is a biocompatible, biodegradable and non-toxic nanoparticles forming polymer. Ultrasonication is a materials mixing technique under high vibration energy. The ultrasonication time affects the particle size. The aim of this study was to determine the effect of the ultrasonication time on physical characteristics of chitosan nanoparticles of suji (Pleomele angustifolia) leaf ethanol extract and its physical stability after cycling test. Ethanol extract of suji leaves (EEDS) was obtained by maceration using 70\% ethanol. Chitosan EEDS nanoparticles were made under ionic gelation method using an ultrasonication time of 3 minutes (FI), 6 minutes (FII), and 9 minutes (FIII). The physical characterization of nanoparticles includes particle size, polydispersity index, and zeta potential. Chitosan EEDS nanoparticles with the best physical characteristics (FIII) were tested for stability using cycling test method. The data obtained were
\end{abstract}


analyzed using the Anova statistical method with a 95\% confidence level. The size of EEDS chitosan nanoparticles (nm) was significantly different in all formulas, FI (374.47), FII (288.43), and FIII (233.37). The polydispersity index of FI (0.38) and FIII (0.65) were significantly different, while FII (0.41) was not significantly different. The zeta potential (mV) FI (51.70), FII (46.10), and FIII (48.60) were not significantly different in all formulas. The physical characteristics of Formula III after Cycling Test showed a particle size of $455.0 \mathrm{~nm}$, a polydispersity index of 0.174 , and a zeta potential of $20.1 \mathrm{mV}$.

Keywords: ultrasonication, nanoparticles, chitosan, cycling test, suji leaf (Pleomele angustifolia)

*Corresponding author:

Malinda Prihantini

Universitas Wahid Hasyim

Jl. Menoreh Tengah X/ 22, Semarang

E-mail: malindap@unwahas.ac.id

\section{PENDAHULUAN}

Tanaman suji mengandung flavonoid yang diduga memiliki aktivitas antioksidan (Prangdimurti dkk., 2006). Flavonoid umumnya memiliki kelarutan yang rendah serta tidak stabil terhadap pengaruh cahaya, oksidasi dan perubahan kimia. Karena itu, apabila teroksidasi, strukturnya akan berubah dan fungsinya sebagai bahan aktif akan berkurang dan bahkan hilang (Kitao dan Sekine.,1994). Salah satu cara melindungi senyawa flavonoid tersebut dibuat nanopartikel. Pada sistem ini senyawa aktif dapat terperangkap, dilarutkan, atau dienkapsulasi pada nanopartikel matriks (Mohanraj dan Chen, 2006) sehingga dapat melindungi senyawa aktif tersebut dari pengaruh kondisi lingkungan. Pembuatan nanopartikel juga berfungsi untuk meningkatkan penetrasi pada lapisan kulit (Santini dkk., 2015).

Kusuma (2018) mengembangkan sistem nanopartikel untuk daun suji menggunakan metode gelasi ionik dengan metode pencampuran menggunakan pengaduk magnetik. Namun, hasilnya belum optimal karena ukuran partikel dan indeks polidispersitas mengalami kenaikan selama penyimpanan. Ulum (2018), mengembangkan sistem nanopartikel untuk daun sawo menggunakan gelasi ionik dengan metode pencampuran ultrasonikasi dan didapatkan ukuran partikel pada rentang 400-500 $\mathrm{nm}$. Meningkatnya kecepatan dan lama pencampuran dalam pembentukan nanopartikel dapat menurunkan ukuran partikel hingga pada titik optimalnya (Gupta dan Karar, 2011; Dangi dan Shakya, 2013). Semakin lama pengadukan akan menghasilkan ukuran partikel yang semakin kecil karena semakin banyak partikel yang terpecah menjadi partikel berukuran nano. Waktu sonikasi pada rentang optimal diketahui akan menghasilkan ukuran partikel yang cenderung lebih homogen dan stabil secara fisika (Delmifiana dkk., 2013). Karena itu perlu diteliti pengaruh waktu ultrasonikasi terhadap karakteristik fisika nanopartikel EEDS dan uji stabilitas fisikanya.

\section{METODE PENELITIAN Bahan dan Alat}

Bahan yang digunakan adalah daun suji (Pleomele angustifolia) diperoleh dari Pekalongan Jawa Tengah Indonesia, etanol 70\% (hasil preparasi di laboratorium), kitosan (pharmaceutical grade), natrium tripolifosfat (NaTPP), asam asetat glasial dan aqua de mineralisata. Alat yang digunakan adalah PSA (Particle Size Analyzer) (Horiba SZ-100), Zeta Sizer (Horiba SZ-100), Ultrasonic Homogenizer (Biologics. Inc $300 \mathrm{~V} / \mathrm{T}$ ), satu set alat maserasi, satu set Evaporator (Heidolph), neraca analitik (Ohaus dan Mettler Toledo), Climatic Chamber (Memmert), lemari pendingin/ refrigerator (Sharp), labu ukur, gelas kimia, gelas ukur, mikropipet, vial, pipet tetes, dan peralatan gelas yang umum di laboratorium.

\section{Pembuatan Ekstrak Etanol Daun Suji}

Pengaruh Waktu Ultrasonikasi terhadap Karakteristik Fisika Nanopartikel Kitosan ... (Malinda Prihantini) 
EEDS diperoleh dari hasil maserasi menggunakan etanol 70\% yang dapat menyari senyawa golongan flavonoid dalam EEDS. Etanol sebagai penyari relatif tidak toksik dibandingkan metanol dan lebih cepat menguap dibandingkan air (Agustin dan Ismiyati, 2015). Maserasi dibagi dalam dua proses, pertama maserasi dengan perbandingan 1:7 selama 3 hari, diikuti dengan proses remaserasi menggunakan perbandingan 1:3 dengan pelarutnya selama 3 hari sambil sesekali diaduk. Maserat I dan II dicampur, kemudian diuapkan pelarutnya menggunakan rotary evaporator dengan suhu $50^{\circ} \mathrm{C}$ hingga diperoleh ekstrak kental, lalu disimpan dalam wadah kaca berwarna gelap terlindung dari cahaya dan ditimbang bobotnya untuk menghitung rendemen ekstrak yang didpatkan, kemudian disimpan di dalam desikator untuk mengurangi kelembaban pada ekstrak. Rendemen ekstrak dihitung menggunakan persamaan di bawah ini.

$$
\text { Rendemen }=\frac{\text { Berat ekstralk daun sujj yang dihasilkan }}{\text { Berat serbulk simplisisia daun sujji }} \mathrm{X} 100 \mathrm{~g}
$$

\section{Pembuatan Nanopartikel Kitosan Ekstrak Etanol Daun Suji.}

Nanopatikel kitosan EEDS dibuat dengan metode gelasi ionik dengan pencampuran menggunakan ultrasonikasi. Pembuatan nanopartikel kitosan EEDS dibuat konsentrasi kitosan $0,2 \% \mathrm{~b} / \mathrm{v}$ yang dilarutkan ke dalam asam asetat $1 \% \mathrm{~b} / \mathrm{v}$. Campuran disonifikasi menggunakan alat ultrasonik selama 10 menit dengan pulser 50 dan power 20 bar sampai kitosan terlarut sempurna. Dibuat larutan NaTPP 0,1\% b/v yang dilarutkan dalam aqua demineralisata menggunakan alat ultrasonik selama 10 menit dengan pulser 50 dan power 20 bar . Campuran kedua bahan tersebut disonifikasi menggunakan alat ultrasonik selama 2 menit. Dibuat larutan stok EEDS, dengan menimbang $100 \mathrm{mg}$ EEDS dilarutkan dalam $1 \mathrm{~mL}$ etanol $70 \%$. Kemudian ekstrak yang sudah dilarutkan dengan etanol 70\% dimasukkan ke dalam campuran larutan kitosan 0,1\% dan NaTPP $0,2 \%$ yang sudah disonifikasi. Campuran disonifikasi menggunakan alat ultrasonik dengan variasi lama waktu pencampuran yaitu FI 3 menit, FII 6 menit dan FIII 9 menit dengan pulser 50 dan power 20 bar sampai terlarut sempurna hingga terbentuk suspensi nanopartikel. Formula nanopartikel kitosan EEDS dapat dilihat pada Tabel I.

Tabel I. Formula Nanopartikel Kitosan EEDS

\begin{tabular}{ll}
\hline \multicolumn{1}{c}{ Bahan } & Formula \\
\hline EEDS (mg/mL) & 100 \\
Kadar kitosan (\% b/v) dalam 6 mL larutan asam asetat glasial 1\% & 0,2 \\
Kadar NaTPP (\% b/v) dalam 1 mL larutan air & 0,1 \\
Rasio massa Kitosan : NaTPP & $12: 1$ \\
\hline
\end{tabular}

\section{Pengukuran Ukuran Nanopartikel dan Indeks Polidispersitas}

Ukuran nanopartikel dan indeks polidispersitas diperoleh melalui pengukuran menggunakan alat PSA. Volume sampel yang digunakan sebanyak $10 \mathrm{~mL}$ untuk masing-masing formula dan dilakukan replikasi sebanyak 3 kali. Nanopartikel dimasukkan ke dalam kuvet. Selanjutnya PSA dioperasikan.

\section{Pengukuran Potensial Zeta}

Nilai potensial zeta dari nanopartikel diukur dengan menggunakan alat Zeta Sizer. Volume sampel yang digunakan sebanyak $10 \mathrm{~mL}$ untuk masing-masing formula dan dilakukan replikasi sebanyak 3 kali. Nanopartikel dimasukkan ke dalam kuvet kemudian dilakukan pengukuran terhadap potensial zeta menggunakan Zeta Sizer.

\section{Stabilitas Fisika Nanopartikel Kitosan EEDS}

Evaluasi stabilitas fisika dilakukan terhadap formula nanopartikel kitosan EEDS dengan karakteristik fisika terbaik. Nanopartikel kitosan EEDS dimasukkan ke dalam lemari pendingin pada suhu $4^{\circ} \mathrm{C}$ selama 24 jam, kemudian dimasukkan ke dalam climatic chamber bersuhu $40^{\circ} \mathrm{C}$

\footnotetext{
Pengaruh Waktu Ultrasonikasi terhadap Karakteristik Fisika Nanopartikel Kitosan ... (Malinda Prihantini)
} 
selama 24 jam sehingga terjadi 1 siklus. Setelah mengalami 6 siklus cycling test nanopartikel kitosan EEDS diuji kembali karakteristik fisikanya meliputi ukuran partikel, indeks polidispersitas dan potensial zeta.

\section{Analisis Data}

Data hasil karakteristik fisik nanopartikel kitosan EEDS berupa ukuran partikel dan indeks polidispersitas dianalisis secara statistik parametrik yaitu One Way Anova dan Tukey dengan taraf kepercayaan $95 \%$ untuk melihat perbedaan antar formula.

Data hasil karakteristik fisik nanopartikel kitosan EEDS berupa potensial zeta dianalisis menggunakan metode uji statistik non parametrik yaitu Kruskal Wallis dengan taraf kepercayaan 95\% untuk melihat perbedaan antar formula.

\section{HASIL DAN PEMBAHASAN}

Hasil ekstrak kental EEDS didapatkan sebanyak 241,36 g dengan rendemen sebesar 16,53\%. Rendemen EEDS kental dari daun suji yang diperoleh dari sumber yang sama memiliki rendemen 30,73\% (Kusuma, 2018). Perbedaan disebabkan karena pemanenan bahan dilakukan di waktu yang berbeda sehingga kemungkinan senyawa metabolit memiliki persentase kandungan yang berbeda.

Metode gelasi ionik merupakan metode pembuatan nanopartikel yang melibatkan proses sambung silang antara polielektrolit dengan pasangan ion multivalennya. Kitosan merupakan polimer kationik yang dapat membentuk nanopartikel karena dapat menangkap makromolekul (Ribeiro dkk., 2015). Kitosan juga bersifat kompatibel, tidak toksik, mudah terdegradasi, larut dalam larutan asam organik yang pHnya kurang dari 6,5 seperti asam laktat, asam asetat dan lainlain (Ponnuraj dkk., 2015). Pembentukan ikatan sambung silang pada metode gelasi ionik memerlukan agen penyambung silang (crosslinker) berupa senyawa polielektrolit seperti NaTPP. Senyawa NaTPP bersifat amfoterik sehingga ion fosfat (TPP) yang bermuatan negatif akan mengikat gugus amina $\left(\mathrm{NH}_{3}{ }^{+}\right)$yang bermuatan positif dari kitosan sedangkan $\mathrm{Na}^{+}$dari NaTPP akan mengikat ion bermuatan negatif pada senyawa yang terkandung dalam ekstrak. Mekanisme reaksi sambung silang antara kitosan dan TPP ditampilkan pada Gambar 1.

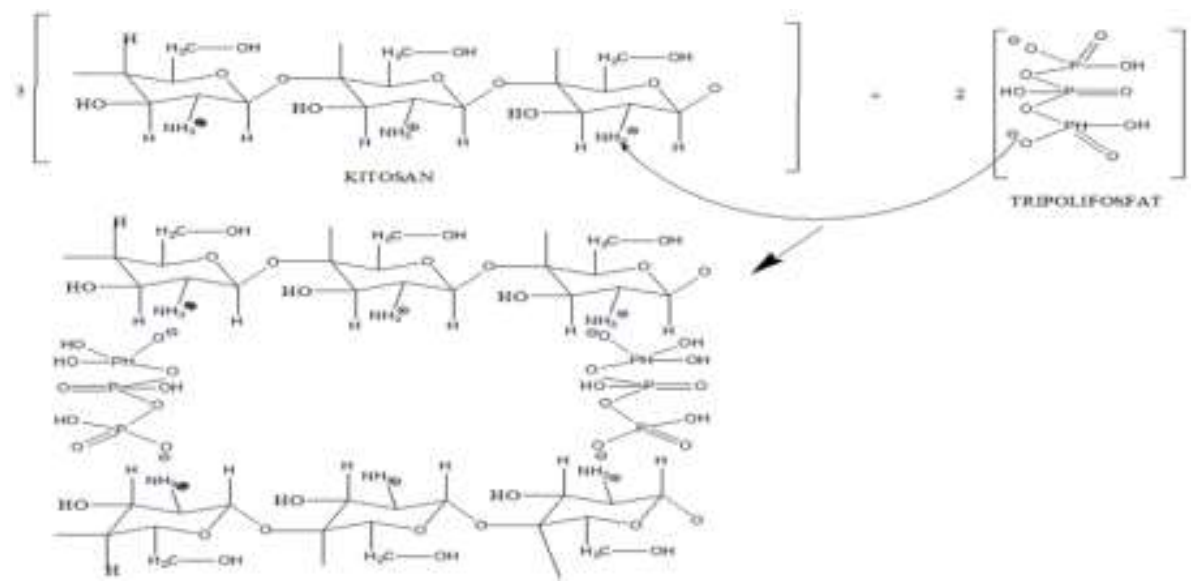

Gambar 1. Mekanisme reaksi sambung silang kitosan-TPP (Hsieh dkk., 2008)

Reaksi sambung silang akan membentuk struktur seperti jaring dan akan melapisi senyawa yang terkandung di dalam ekstrak. Proses sambung silang secara fisika ini menguntungkan karena tidak hanya menghindari penggunaan pelarut organik, tetapi juga mencegah kemungkinan rusaknya bahan aktif yang akan dienkapsulasi dalam nanopartikel kitosan (Kunjachan dkk., 2014). Nanopartikel yang dibuat menggunakan metode gelasi ionik dengan komposisi kitosan dan NaTPP dapat menghasilkan nanopartikel dengan ukuran 250-350 nm dengan efisiensi penjerapan zat aktif sekitar 72,2\% (Dustgania dkk., 2008).

Pengaruh Waktu Ultrasonikasi terhadap Karakteristik Fisika Nanopartikel Kitosan ... (Malinda Prihantini) 
Proses pembentukan partikel menggunakan metode ultrasonikasi melalui pemanfaatan gelombang suara dan getaran dalam memisahkan penggumpalan partikel dan memecahnya menjadi ukuran yang lebih kecil. Peningkatan kecepatan memperbesar intensitas molekul pelarut untuk kontak dengan kitosan sehingga semakin besar intensitas kecepatan maka partikel yang dihasilkan semakin kecil. Namun, hal tersebut hanya berlaku hingga titik optimum dicapai. Berdasarkan hasil optimasi proses menggunakan metode Box-Behnken dinyatakan bahwa waktu sonikasi selama 6-10 menit mampu menghasilkan nanoemulsi yang memiliki karakteristik fisika yang optimal (Suciati dkk, 2019).

Pada awal proses ultrasonikasi, pemutusan rantai kitosan belum terjadi dengan sempurna dan agregat nanopartikel magnetik belum terpisah dengan baik sehingga viskositas masih tinggi, karena medium hanya mengalami perenggangan ikatan sebelum terjadinya pemutusan sempurna ikatan (Ruan dan Jacobi, 2012). Semakin lama waktu proses, pemutusan ikatan dan dispersi agregat menjadi makin sempurna namun tetap dengan ukuran partikel yang cenderung kecil dan homogen. Metode ultrasonikasi juga memiliki kelebihan selain prosesnya yang sederhana, metode ini lebih cepat dan efisien menghasilkan partikel berukuran nano dibandingkan dengan metode konvensional. Hasil ukuran partikel sistem nanopartikel kitosan EEDS untuk FI, FII dan FIII dapat dilihat pada Tabel II.

Tabel II. Hasil Ukuran Partikel Kitosan EEDS

\begin{tabular}{ccccc}
\hline \multirow{2}{*}{ Formula } & \multicolumn{3}{c}{ Ukuran Partikel (nm) } & \multirow{2}{*}{ Rata-rata \pm SD } \\
\cline { 2 - 4 } & Replikasi 1 & Replikasi 2 & Replikasi 3 & \\
\cline { 2 - 4 } FI & 370,90 & 367,00 & 385,50 & $374,47 \pm 9,75$ \\
FII & 287,10 & 272,80 & 305,40 & $287,43 \pm 16,34$ \\
FIII & 234,60 & 233,60 & 231,90 & $233,37 \pm 1,37$ \\
\hline
\end{tabular}

Keterangan:

FI : Formulasi nanopartikel kitosan EEDS dengan variasi lama waktu pencampuran 3 menit.

FII : Formulasi nanopartikel kitosan EEDS dengan variasi lama waktu pencampuran 6 menit.

FIII : Formulasi nanopartikel kitosan EEDS dengan variasi lama waktu pencampuran 9 menit.

Ukuran nanopartikel terkecil ditunjukkan oleh FIII sedangkan yang paling besar ditunjukkan oleh FI. Hasil penelitian menunjukkan bahwa waktu ultrasonikasi berpengaruh terhadap ukuran partikel sistem nanopartikel kitosan EEDS. Waktu ultrasonikasi yang optimum dinilai dari kemampuan melarutkan dan mendistribusikan suatu bahan secara merata di dalam sistem. Semakin lama waktu pencampuran, maka ukuran partikel semakin kecil (Jusnita, 2014). Hal tersebut disebabkan durasi yang lebih lama dari kekuatan radiasi ultrasonik untuk menyebarkan tetesan koloid ke ukuran yang lebih kecil (Li dan Chiang, 2012). Ukuran partikel semakin kecil dengan peningkatan gaya yang diberikan. Menurut Lachman dan Lieberman (1994), jika pencampuran terlalu lambat maka bahan-bahan sulit menjadi homogen karena kurangnya intensitas tumbukan antar partikel. Pada FI dan FII memiliki ukuran partikel yang lebih besar dari FIII hal ini disebabkan pencampuran belum sempurna sehingga mudah terbentuk koloid (Taurina dkk., 2017). Ukuran tersebut telah memenuhi syarat ukuran nanopartikel yaitu kisaran 10-1000 nm (Tiyabooncai., 2003) sehingga FI, FII, dan FIII memenuhi syarat ukuran nanopartikel karena hasil yang diperoleh memiliki ukuran partikel < $1000 \mathrm{~nm}$. Hasil statistik One Way Anova menunjukkan nilai signifikansi $\mathrm{p}<0,05$ yang berarti ada perbedaan bermakna antar formula, selanjutnya hasil uji Tukey menunjukkan bahwa ada perbedaan bermakna ukuran partikel antar formula.

Hasil pengukuran indeks polidispersitas nanopartikel kitosan EEDS dapat dilihat pada Tabel III. Indeks polidispersitas yang paling kecil ditunjukkan oleh FI sedangkan yang paling besar ditunjukkan oleh FIII. Nilai indeks polidispersitas menunjukkan keseragaman ukuran partikel. Semakin kecil nilai indeks polidispersitas maka ukuran partikel semakin homogen (Yuan dkk., 2008). Indeks polidispersitas mendekati 0 menunjukkan ukuran partikel yang semakin seragam dan

Pengaruh Waktu Ultrasonikasi terhadap Karakteristik Fisika Nanopartikel Kitosan ... (Malinda Prihantini) 
homogen (Haque, 2015). Nilai indeks polidispersitas menunjukkan distribusi ukuran yang dapat mempengaruhi penghantaran obat, pelepasan obat dan stabilitas nanopartikel (Ko dkk., 2002). Nanopartikel dengan nilai indeks polidispersitas 1 memiliki distribusi ukuran yang sangat luas dan mengandung partikel besar atau agregat yang dapat mengalami sedimentasi. Nilai indeks polidispersitas 0,01 sampai 0,5 biasanya dimiliki oleh sistem monodispersi. Sedangkan indeks $>0,7$ menyatakan sistem nanopartikel dengan distribusi ukuran partikel yang sangat luas (Nidhin dkk., 2008). Indeks polidispersitas ini memberikan informasi mengenai kestabilan fisik suatu sistem dispersi yang terbentuk bersifat lebih stabil untuk jangka panjang (Gao dkk., 2008).

Tabel III. Hasil Pengukuran Indeks Polidispersitas Nanopartikel Kitosan EEDS

\begin{tabular}{ccccc}
\hline \multirow{2}{*}{ Formula } & \multicolumn{3}{c}{ Indeks Polidispersitas } & \multirow{2}{*}{ Rata-rata \pm SD } \\
\cline { 2 - 4 } & Replikasi 1 & Replikasi 2 & Replikasi 3 & \\
\hline FI & 0,50 & 0,31 & 0,32 & $0,38 \pm 0,11$ \\
FII & 0,53 & 0,29 & 0,41 & $0,41 \pm 0,12$ \\
FIII & 0,64 & 0,68 & 0,65 & $0,65 \pm 0,03$ \\
\hline
\end{tabular}

Keterangan :

FI : Formulasi nanopartikel kitosan EEDS dengan variasi lama waktu pencampuran 3 menit.

FII : Formulasi nanopartikel kitosan EEDS dengan variasi lama waktu pencampuran 6 menit.

FIII: Formulasi nanopartikel kitosan EEDS dengan variasi lama waktu pencampuran 9 menit.

Nilai indeks polidispersitas yang dihasilkan dari ketiga formula menunjukkan bahwa distribusi ukuran partikel pada FI dan FII yang dihasilkan bersifat monodispers, artinya distribusi partikel dari kedua formula tersebut memiliki ukuran partikel yang seragam, dengan nilai rata-rata indeks polidispersitas yang dihasilkan berada pada rentang 0,4-0,5 sehingga menunjukkan nanopartikel kitosan EEDS memiliki kecendrungan stabil secara fisik maka tidak menyebabkan partikel saling beragregasi (Avadi 2010; Rahmawanty, 2014). Walaupun demikian, nilai indeks polidispersitas yang dihasilkan dari FIII masih dapat diterima karena distribusi ukuran droplet yang seragam dan homogen yaitu <0,7 (Abdellatif dkk., 2015). Berdasarkan data tersebut, dapat dinyatakan bahwa peningkatan waktu pencampuran mengakibatkan indeks polidispersitas yang semakin tinggi. Hal ini karena semakin tingginya vibrasi getaran dari ultrasonik akan mengakibatkan semakin kecil ukuran partikel. Semakin kecil ukuran partikel, ketidakteraturan antar partikel akan semakin tinggi sehingga partikel koloid yang dihasilkan menjadi tidak stabil dan memiliki kecenderungan saling bersatu untuk menstabilkan membentuk suatu agregat yang lebih besar. Agregat-agregat yang terbentuk memiliki kecenderungan ukuran partikel yang tidak seragam sehingga nilai indeks polidispersitasnya semakin tinggi. Hasil statistik One Way Anova menunjukkan nilai signifikansi p $<0,05$ yang berarti ada perbedaan bermakna antar formula, selanjutnya uji Tukey menunjukkan bahwa FI dan FIII ada perbedaan bermakna nilai indeks polidispersitas, sedangkan FI dan FII serta FII dan FIII tidak ada perbedaan bermakna nilai indeks polidispersitas.

Nilai potensial zeta dari FI, FII, dan FIII yaitu $+51,70 \mathrm{mV}$, 46,10 mV, dan 48,60 mV. Hasil tersebut menandakan bahwa nanopartikel kitosan EEDS memiliki kestabilan yang baik, karena memiliki nilai potensial zeta lebih dari $30 \mathrm{mV}$ (Akhtar dkk, 2012). Idealnya muatan dari potensial zeta harus lebih tinggi dari pada medium pendispers untuk mencegah adanya agregasi. Sistem dispersi dengan nilai muatan potensial zeta yang rendah lebih mudah untuk membentuk agregat seiring dengan adanya gaya Van der Waals (Nanocomposix, 2012). Muatan positif pada potensial zeta kemungkinan berasal dari muatan positif dari kitosan yang tidak terikat dengan muatan negatif dari tripolifosfat. Gugus amina $\left(\mathrm{NH}_{3}{ }^{+}\right)$yang bermuatan positif dari kitosan akan berikatan dengan ion fosfat $\left(\mathrm{P}_{3} \mathrm{O}_{10}\right)$ dari NaTPP yang bermuatan negatif, sedangkan muatan positifnya $\left(\mathrm{Na}^{+}\right)$akan berikatan dengan muatan negatif dari zat aktif sehingga zat aktif EEDS terenkapsulasi dengan baik dan terdistribusi di dalam polimer kitosan.

Pengaruh Waktu Ultrasonikasi terhadap Karakteristik Fisika Nanopartikel Kitosan... (Malinda Prihantini) 
Nilai potensial zeta secara umum digunakan untuk mengetahui muatan partikel dan kestabilan nanopartikel. Pengukuran potensial zeta dapat memberikan informasi mengenai stabilitas sistem dispersi koloidal saat penyimpanan yaitu kemungkinan terbentuknya agregat pada partikel yang bermuatan. Selain itu, muatan permukaan partikel dapat digunakan sebagai informasi apakah zat aktif terenkapsulasi dalam nanopartikel atau hanya teradsorpsi di permukaan nanopartikel (Mohanraj dan Chen., 2006). Hasil uji statistik non parametrik menggunakan Kruskall Wallis menunjukkan nilai signifikansi $0,061(p>0,05)$, yang berari secara statistik tidak terdapat perbedaan bermakna dari lama waktu pencampuran terhadap nilai potensial zeta sediaan nanopartikel kitosan EEDS.

Hasil evaluasi stabilitas fisika nanopartikel kitosan EEDS setelah mengalami cycling test selama 6 siklus (12 hari penyimpanan) mengalami peningkatan ukuran partikel menjadi 455,0 nm, peningkatan nilai indeks polidispersitas menjadi 0,174 dan penurunan potensial zeta menjadi 20 Mv. Peningkatan ukuran partikel selama penyimpanan cycling test terjadi karena adanya pengaruh gravitasi dalam sistem dispersi koloid dapat mengakibatkan partikel saling menempel satu sama lain dan membentuk agregat dengan ukuran yang meningkat secara berturut-turut (Attwood, 2002; Florence dan Attwood, 1998). Terjadinya agregasi tersebut juga berpengaruh terhadap potensial zeta yang mengakibatkan terjadinya penurunan, sedangkan nilai indeks polidispersitas yang menurun kemungkinan disebabkan karena agregat yang terbentuk memiliki ukuran yang hampir seragam atau lebih homogen dari segi ukuran. Masalah stabilitas ini dapat diatasi dengan meningkatkan konsentrasi kitosan dalam formula sehingga viskositas dalam sistem suspensi nanopartikel menjadi lebih tinggi dan kecepatan agregasi menurun sejalan dengan Hukum Stokes.

\section{KESIMPULAN}

Hasil karakteristik fisik nanopartikel kitosan EEDS dengan metode ultrasonikasi pada semua formula memenuhi syarat karakteristik fisika nanopartikel, yaitu ukuran partikel FI $(374,47 \mathrm{~nm})$, FII $(288,43 \mathrm{~nm})$, dan FIII $(233,37 \mathrm{~nm})$. Indeks polidispersitas FI $(0,38)$, FII $(0,41)$, dan FIII $(0,65)$. Potensial zeta FI $(51,70 \mathrm{mV})$, FII $(46,10)$, dan FIII $(48,60)$. Hasil Anova ukuran partikel menunjukkan adanya perbedaan bermakna pada semua formula, uji indeks polidispersitas FI dan FIII berbeda bermakna, potensial zeta menunjukkan adanya perbedaan, tetapi tidak bermakna pada semua formula. Karakteristik fisika Formula III setelah Cycling Test menunjukkan ukuran partikel $455,0 \mathrm{~nm}$, indeks polidispersitas 0,174 , dan potensial zeta $20,1 \mathrm{mV}$.

\section{DAFTAR PUSTAKA}

Abdellatif, A. A. H., dan Abou-taleb, A. H. , 2015, Optimization of nano-Emulsion Formulation for Ceratin Emollient Effect, World Journal of Pharmacy and Pharmaceutical Sciences, 4 (12): 1314-1328.

Agustin, D., dan Ismiyati., 2015, Pengaruh Konsentrasi Pelarut Pada Proses Ekstraksi Antosianin Dari Bunga Kembang Sepatu, Skripsi, Universitas Muhammadiyah Jakarta.

Akhtar, F., Rizvi, M.M.A., Kar, S.K., 2012, Oral Delivery of Curcumin Bound to Chitosan Naoparticles Cured Plasmodium yoellii Infected Mice. Biotechnology Advances, 30 (1): 310- 320.

Attwood, D., 2002, Pharmaceutics, In The Science of Dosage Form Design 2nd ed., Edited by Aulton, M. E., Churchill Livingstone, Edinburgh, 70-100.

Avadi M., 2010, Preparation and Characterization Of Insulin Nanoparticles Using Chitosan and Arabic Gum With Ionic Gelation Method, Journal Nanomed: Nanotech, Biol Med. 6 : 5863.

Dangi, R., Shakya, S., 2013, Preparation, Optimization and Characterization of PLGA Nanoparticle, International Journal of Pharmaceutical and Life Sciences. 4(7): 2810-2818.

Delmifiana, B. dan Astuti, 2013, Pengaruh Sonikasi Terhadap Struktur dan Morfologi Nanopartikel Magnetik yang Disintesis dengan Metode Kopresipitasi, Jurnal Fisika Unand, 2(3).

Dustgania, A., frahani, E. V., dan Imani, M., 2008, Preparation of Chitosan Nanopaerticle Loaded Pengaruh Waktu Ultrasonikasi terhadap Karakteristik Fisika Nanopartikel Kitosan ... (Malinda Prihantini) 
by Dexamethasone Sodium Phosphate, Iranian Journal of Pharmaceutical Science, 4 (2):111-114.

Florence, A. T., Attwood, D., 1998, Physicochemical Principles of Pharmacy, 3rd ed.; Pharmaceutical, Press, London, 255-264.

Gao, L., Zhang, D., dan Chen, M., 2008, Drug Nanocrystals for The Formulation of Poorly Soluble Drugs and Its Application as a Potential Drug Delivery System, Journal of Nanoparticle Research, 10(5), 845-862.

Gupta, V. dan Karar, PK., 2011, Optimization of Process Variables for the Preparation of ChitosanAlginate Nanoparticle, International Journal of Pharmacy and Pharmaceutical Sciences., 3(2): 78-80.

Haque, F. A. K, 2015, Karakteristik Nanoemulsi Ekstrak Jahe (Zingiber officinale var. amarum), Skripsi, Institut Pertanian Bogor, Bogor.

Hsieh, F. M., Huang, C., Lin, T. F., Chen, Y. M., dan Lin, J. C., 2008, Study of Sodium Tripolyphosphate-Crosslinked Chitosan Beads Entrapped with Pseudomonas putida for Phenol Degradation, Process Biochemistry, 43(1): 83-92.

Jusnita, N., 2014, Produksi Nanoemulsi Ekstrak Temulawak dengan Metode Homogenisasi, Tesis, Institut Pertanian Bogor, Bogor.

Kitao, S., dan Sekine, H., 1994, $\alpha$-D-glukosyl Transfer to Phenolic Compounds by Sucrose Phosphorylase from Leuconostoc Mesenteroides and Production of $\alpha$-arbutin, Bioscience, Biotechnology. Biochemistry, 58 (1): 38-42.

Ko JA., Park HJ., Hwang SJ., Park JB., Lee JS., 2002, Preparation and Characterization of Chitosan Microparticles Intended for Controlled Drug Delivery, International Journal of Pharmaceutics, 249 (1-2): 165-174.

Kunjachan, S., Jose, S., dan Lammers, T., 2014,. Understanding The Mechanism of Ionic Gelation For Synthesis of Chitosan Nanoparticles Using Qualitative Techniques. Asian Journal of Pharmaceutics (AJP): 4(2).

Kusuma, H.S., 2018, Pembuatan dan Karaketisasi Nanopartikel Ekstrak Etanol Daun Suji (Pleomele angustifolia) pada Berbagai Variasi Komposisi Kitosan, Skripsi, Universitas Wahid Hasyim Semarang.

Lachman, L., dan Lieberman, H. A., 1994, Teori dan Praktek Farmasi Industri, Edisi Kedua, diterjemahkan oleh Siti Suyatmi, UI Press, Jakarta, 1091-1098.

Li, P. H., dan Chiang, B. H., 2012, Process Optimization and Stability of D-Limonene-In-Water Nanoemulsions Prepared by Ultrasonic Emulsification Using Response Surface Methodology. Ultrasonics sonochemistry, 19(1):192-197.

Mohanraj U. J dan Y Chen, 2006, Nanoparticles - A Review, Tropical Journal of Pharmaceutical Research, 5(1):561-573.

Nanocomposix, 2012, Zeta Potential Analysis Of Nanoparticles Vol 1.1., NanoComposix, San Diego

Nidhin M., Indumathy R., Sreeram KJ., Nair BU, 2008, Synthesis of Iron Oxide Nanoparticles of Narrow Size Distribution on Polysaccharide Templates, Journal Bull. Mater. Sci, 31 (1): 93-96.

Ponnuraj, R., Janakiraman, K., Gopalakrishnan, S., Senthilnathan, K., and Saravanan, P., 2015, Formulation and Characterization of Epigallocatechin Gallate Nanoparticles, Indo American Journal of harmaceutical Research, 5(1).

Prangdimurti, E., Muchtadi D., Aswatan M., Zakaria F., 2006, Aktivitas Antioksidan Ekstrak Daun Suji (Pleomele angustifolia, N.E Brown), Jurnal Teknoligi dan Industri Pangan, (17)2 .

Rahmawanty D., Effionora A., Anton, B., 2014, Formulasi Gel Menggunakan Ikan Haruan (Channa striatus) sebagai Penyembuh Luka, Jurnal Media Farmasi. 11(1): 29-40.

Ribeiro, R. C. D. A., Barreto, S. M. A. G., Ostrosky, E. A., Rocha-Filho, P. A. D., Veríssimo, L. M., dan Ferrari, M., 2015, Production and Characterization of Cosmetic Nanoemulsions Containing Opuntia ficus-Indica (L.) Mill Extract as Moisturizing Agent, Molecules, 20

Pengaruh Waktu Ultrasonikasi terhadap Karakteristik Fisika Nanopartikel Kitosan... (Malinda Prihantini) 
(2): 2492-2509.

Ruan, B., dan Jacobi, A. M., 2012, Ultrasonication Effects on Thermal and Rheological Properties of Carbon Nanotube Suspensions. Nanoscale Research Letters, 7(1): 127.

Santini B., Ivan Z., Marzil R., 2015, Cream Formulation Impact on Topical Administration of Engineered Colloidal Nanoparticles, Plos One Journal, 10.1371

Suciati, T., Prihantini, M., Fidrianny, I., 2019, Optimasi Nanoemulsi A/M/A Ekstrak Etanol Daun Binahong dan Konjugat AG-Kitosan Menggunakan Desain Box-Behnken, Jurnal Ilmu Kefarmasian Indonesia, 17(2): 150-159.

Taurina, Wintari., Sari, Rafika., Hafinur, Uray C., Wahdaningsih, S., dan Isnindar, 2017, Optimasi Kecepatan dan Lama Pengadukan Terhadap Ukuran Nanopartikel Kitosan-Ekstrak Etanol 70\% Kulit Jeruk Siam (Citrus nobilis, L.var Microcarpa), Tradit. Med. Journal, 22(1): 1620.

Tiyaboonchai W., 2003, Chitosan Nanoparticles : A Promising System for Drug Delivery, Naresuan University Journal, 11(3): 51-66.

Ulum, S., 2018, Pembuatan dan Karaketisasi Nanopartikel Ekstrak Etanol Daun Sawo (Manilkara zapota, L.) pada Berbagai Variasi Komposisi Kitosan-Natrium Tripolifosfat, Skripsi, Universitas Wahid Hasyim, Semarang.

Yuan Y, Gao Y, Zhao J, Mao L., 2008, Characterization and Stability Evaluation of B-Carotene Nanoemulsions Prepared by High Pressure Homogenization under Various Emulsifying Conditions, Food Research International, 41: 61- 68. 